\title{
Evidence of a planktonic food web response to changes in nutrient input dynamics in the Mar Menor coastal lagoon, Spain
}

\author{
A. Pérez-Ruzafa ${ }^{1}$, J. Gilabert ${ }^{2}$, J.M. Gutiérrez ${ }^{1}$, A.I. Fernández ${ }^{1}$, C. Marcos $^{1} \&$ S. Sabah ${ }^{1}$ \\ ${ }^{1}$ Department of Ecology and Hydrology, University of Murcia, Campus de Espinardo, 30100-Murcia, Spain \\ ${ }^{2}$ Department of Chemical and Environmental Engineering, Polytechnic University of Cartagena, Alfonso XIII, 44, \\ 30202 Cartagena, Spain
}

Key words: coastal lagoon, eutrophication, pelagic food web, top-down control, jellyfish, size biomass-spectra

\begin{abstract}
Nutrient input dynamics in the Mar Menor coastal lagoon has recently changed as a consequence of changes in agricultural practises. An interannual comparison of the environmental variables and the planktonic biomass size-spectra was performed between 1988 and 1997. While nitrate concentration was low in 1988, the values in 1997 increased considerably. Since 1995, two alloctonous jellyfish species (Rhyzostoma pulmo and Cotylorhiza tuberculata) occurred in large numbers in summer time and reached peak abundance in summer of 1997. The size-spectra analysis comparison revealed that, in spite of changes in nutrient input that stimulated the growth of larger phytoplankton cells, there were no significant differences in the spectra slope which followed a similar seasonal trend in both years. However, the plankton biovolume considered under the size range compared (between 2 and $1000 \mu \mathrm{m}$ diameter) was, paradoxically, always lower in 1997. Given that there were higher nutrient levels in 1997, this finding suggest a strong top-down control mechanism of size structure. Gut contents of jellyfishes showed their preference for large diatoms, tintinnids, veliger larvae and copepods, corroborating that size structure in these assemblages can be subject to top-down control. The implication of these results is that the feeding activities of large gelatinous zooplankton (jellyfishes) may play an important role controlling the consequences of eutrophication within the Mar Menor coastal lagoon.
\end{abstract}

\section{Introduction}

Nutrients are considered the main limiting factor for phytoplankton growth in shallow temperate ecosystems, where photon flux through the water column does not impose restrictions to photosynthetic requirements across seasons. The response of planktonic food webs to nutrient enrichment in coastal marine ecosystems varies widely world wide due to the broad range of both direct and indirect effects of the eutrophication process (Kerfoot \& Sih, 1987; De Angelis, 1992; Scheffer, 1998). When a bottom-up control exists, the general patterns described include the substitution of macrophytes by macroalgae at the benthic level in a first step and then a change to a phytoplankton based system with anoxic events originated when light penetration is severely limited by phytoplankton absorption (Niehnius, 1992). However, the response of ecosystems to nutrient load increase dif- fers widely because biological control mechanisms of the eutrophication process are not always the same. Predation can be a very efficient control mechanism providing alternative energy flow pathways in the food web by removing excess biomass generated by excess nutrients.

Organisms fit themselves to the environmental conditions determining the planktonic structure. Changes in taxonomic composition related to the eutrophication process influence the size structure (Sprules \& Knoechel, 1984; Sprules \& Munawar, 1986). Theory and natural patterns across ecosystems (Awagin et al., 2000) state that small phytoplankton cells dominate in temperate oligotrophic waters whilst large ones are comparatively more abundant in colder and rich nutrient waters. The implications of cell size for nutrient uptake (see review by Chisholm, 1992), pointed out the competitive advantage of small cells in poor nutrient water due to their higher surface to 
volume ratio which allows more efficient uptake and diffusion of nutrients. Although small cells also grow under high nutrient regimes, large cells outcompete them due to competitive advantages derived from larger size, such as better light adaptation (Geider et al., 1986) or predation avoidance (Raymont, 1963).

Abundance and size of cells determine both quantity and kind of potential predators, as grazing rates for most planktonic heterotrophs are size dependent (e.g. Frost, 1972; Bartram, 1980; Peters, 1994). In this way, changes in the size structure of phytoplankton assemblages may, therefore, induce changes in zooplankton population regulating the increase of different size organisms and, at the same time, sizedependent complex interactions in the food web determine, in turn, most of the changes in the plankton structure. However, the mechanisms and processes (including size-dependent relationships) involved in algal blooms or in the massive proliferations of jellyfishes are something not yet well understood.

The objectives of this paper are (a) to examine changes in the structure and size spectrum of the planktonic community in relation to differences in the nutrient loads, and (b) to asses the effect of the proliferation of jellies on the pelagic food web structure. To do this, we compare the plankton size structure in the Mar Menor coastal lagoon before and after the nutrient input regime changed over a 9-year period between 1988 and 1997, which lead into a massive proliferation of jellyfishes.

\section{Description of the study area}

The Mar Menor is a hypersaline coastal lagoon with a surface area of about $135 \mathrm{~km}^{2}$. It is located in a semiarid region (113-498 $\mathrm{mm}$ mean annual rainfall) at the Southeast of Spain $\left(37^{\circ} 44^{\prime} \mathrm{N}, 0^{\circ} 47^{\prime} \mathrm{W}\right)$ on the Mediterranean coast (Fig. 1). The mean depth is $3.5 \mathrm{~m}$ with a maximum depth of $6 \mathrm{~m}$. The salinity of the lagoon waters ranges between 42 and 47 psu, due to high evaporation and low exchange rates with the Mediterraean. Water temperature ranges from 10 ${ }^{\circ} \mathrm{C}$ in winter to $31{ }^{\circ} \mathrm{C}$ in summer. No stratification exists in the water column. The Mar Menor is one of the largest coastal lagoons on the Mediterranean coast supporting a wide range of uses, including large tourist resorts and intensive agriculture. It is isolated from the Mediterranean Sea by a $22 \mathrm{~km}$ long sandy bar (La Manga), crossed by five very shallow channels. In the early 1970s, one of these channels (El Estacio) was
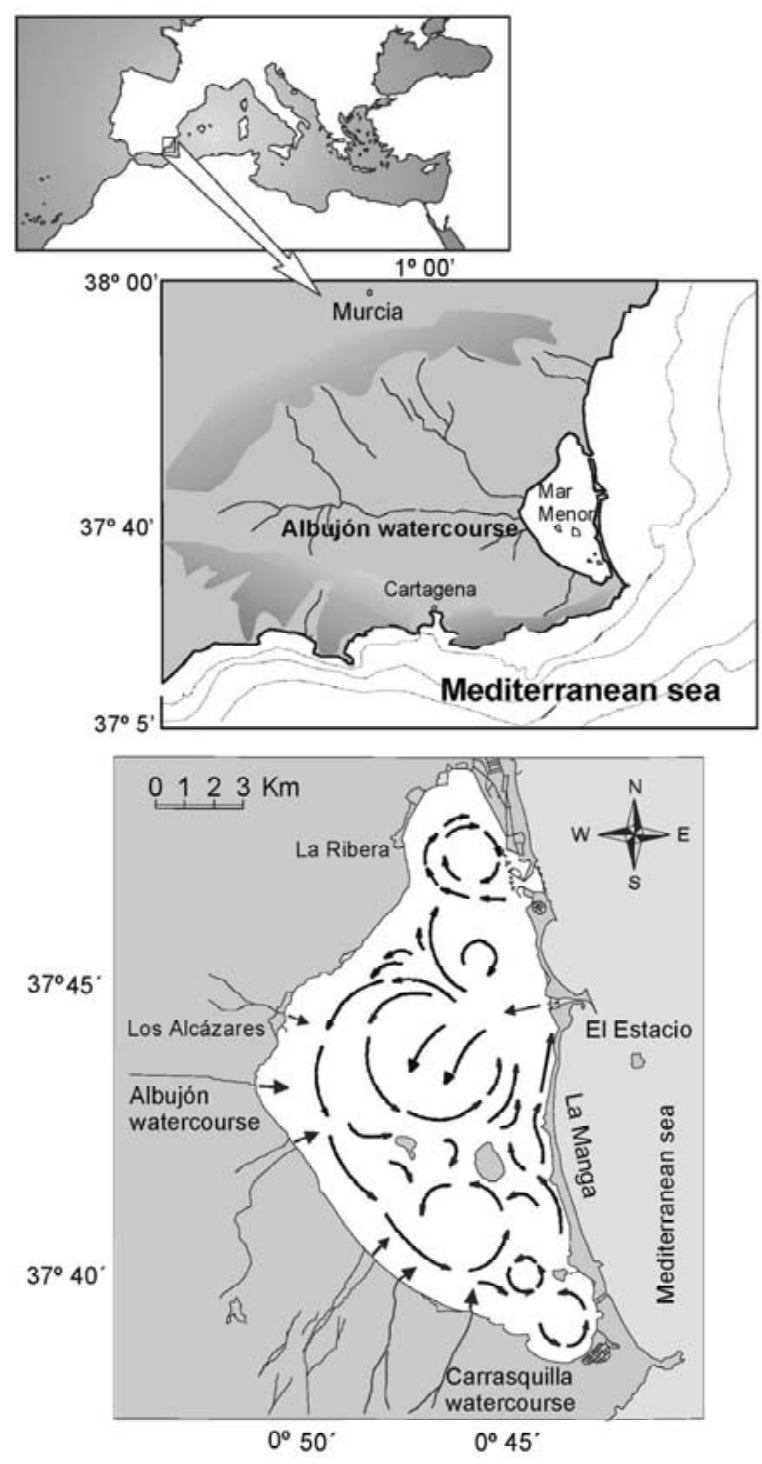

Figure 1. Location of the Mar Menor lagoon with main watercourses on the watershed and circulatory model.

dredged and widened to make it navigable. Since then, it has become the main connection with the sea and the average water residence time in the lagoon is about 0.79 years (A. Pérez-Ruzafa, 1989).

In the 1970s, primary productivity was mainly benthic and the main macrophyte was the phanerogam Cymodocea nodosa. During the early 1980s, after the enlargement of El Estacio, the bottoms were covered by a mixed meadow of Cymodocea nodosaCaulerpa prolifera, which biomass was about $280 \mathrm{~g}$ dw $\mathrm{m}^{-2}$ (I.M. Pérez-Ruzafa, 1989; Terrados \& Ros, 1991). By the mid 1980s, a dense bed of the invasive 
macroalga, Caulerpa prolifera, covered most of the bottom, restricting the seaweed Cymodocea nodosa to small patches in shallowest areas. The high benthic macrophyte biomass contrasted with the low phytoplanktonic density (Ros \& Miracle, 1984) and the oligotrophy of the waters (Gilabert, 1992).

Several watercourses drain into the lagoon (Fig. 1) but only become functional under episodic rainfall events as high evaporation and infiltration rates prevent waters to reach the lagoon under normal conditions (Lillo, 1978). However, during the last 10 years agriculture in the watershed has changed from extensive dry crop farming to intensively irrigated crops. Water for irrigation is diverted from rivers to the North (Tajo-Segura rivers diversion). These changes led to a rise in phreatic levels, as the overexploitation of ground water decreased. Some watercourses, such as El Albujón and La Carrasquilla, now maintain a regular flux feed by ground water with high nitrate levels to the lagoon. At the same time, increasing touristic activities lead to a rise in urban sewage which usually is the main input of phosphate in Mediterranean coastal lagoons (Vaulot \& Frisoni, 1986) however, meanwhile in 1988 no urban wastewater treatment plants were installed, in 1997 they exist for the main cities, as La Ribera and Los Alcázares.

In the mid 1980s, two allochtonous species of jellyfish (Rhyzostoma pulmo and Cotylorhiza tuberculata) entered into the lagoon from the Mediterranean (A. Pérez-Ruzafa, 1989). After an initial period of slow growth, their population grew up to reach considerably greater quantities (Pérez-Ruzafa et al., 1997, technical report), resulting in serious inconveniences to tourism.

\section{Materials and methods}

Results obtained from two sampling programmes carried out in 1988 and 1997 are compared in this study. Figure 2 shows the location map of the stations sampled weekly in 1997. Environmental variables (temperature, salinity, nutrient concentrations, i.e. nitrate and phosphate), were measured at all stations. In addition, plankton samples were taken at sampling stations 2, 5, 10 and 18. In 1988, only station 2 was sampled.

Water samples for environmental variable measurements were taken at $1 \mathrm{~m}$ depth with a Niskin bottle. Samples for nutrient analysis were kept in dark and at $4{ }^{\circ} \mathrm{C}$ in the field and stored at $-28{ }^{\circ} \mathrm{C}$. Nitrate $\left(\mathrm{NO}_{3}-\right.$

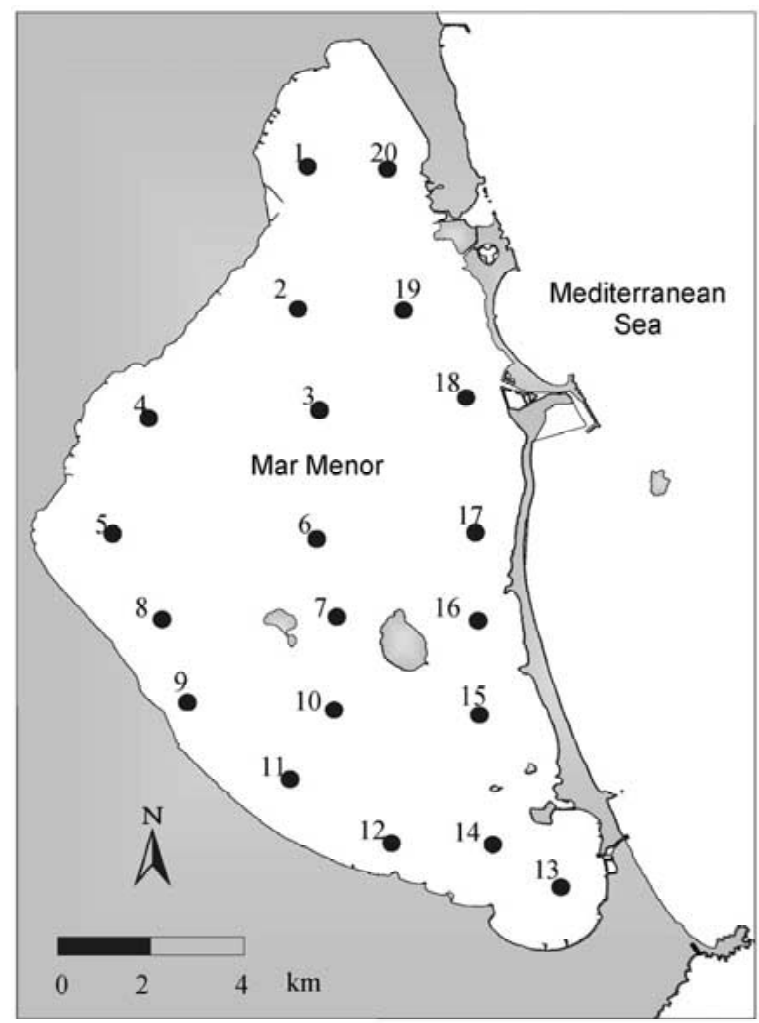

Figure 2. Map showing the location of the sampling stations used in this study.

N) was determined following the method described by Parsons et al. (1984). Phosphate $\left(\mathrm{PO}_{4}-\mathrm{P}\right)$ was analysed following the method described by Fernández et al. (1985) in 1988, whilst the method described in Parsons et al. (1984) was used during 1997. For salinity determination, a Beckman RS 7B salinometer was used in both years.

Field sampling for plankton composition and size structure study was described in Gilabert et al. (1990). A sub-sample of $250 \mathrm{ml}$ obtained with Niskin bottle was stored in a dark glass bottle and preserved with Lugol acetic solution to study nanoplankton $(2-20 \mu \mathrm{m}$ of Estimated Spherical Diameter) and microplankton (20-200 $\mu \mathrm{m}$ ESD). To estimate the abundance of the larger fraction of microplankton, 51 water sample was filtered through a $45 \mu \mathrm{m}$ gauze. The retained material was preserved in 5\% formaldehyde. Finally, two horizontal tows using a Bongo (100 $\mu \mathrm{m}$ gauze) and a Juday-Bogorov (250 $\mu \mathrm{m}$ gauze) net, both equipped with flow meters, were carried out to estimate the abundance of the mesoplankton ( $>200 \mu \mathrm{m}$ ESD). An extra net of $500 \mu \mathrm{m}$ gauze was added in 1997 to count 
and measure fish larvae, ephyrae and juvenile stages of jellyfishes.

Census for adult jellyfishes abundance were only performed in 1997 as for 1988 no Rhyzostoma pulmo neither Cotylorhiza tuberculata were found at the sampling station. Adult jellyfish densities were estimated at the 20 sampling stations by combining simultaneous visual census performed from the boat and towed nets at a velocity of 1 not. The maximum value obtained for each sampling was considered as the more realistic data of the population. Several individuals were taken and measured in laboratory to obtain size frequency distributions. For gut content analysis, individuals were taken directly from the water column with a polyethylene bag; they were externally washed and carefully fixed with $5 \%$ formaldehyde-sea water solution in another bag. In the laboratory, individuals were dissected and gastric cavity and oral channels washed carefully with sprayer distilled water. Bag contents as well as washed materials were sequentially sieved through $1 \mathrm{~mm}$ (mainly for body pieces) and 56 $\mu \mathrm{m}$ (for gut contents) sieve. The filtrated material was preserved in $5 \%$ formaldehyde-sea water solution for later microscopic analysis.

In the laboratory, to estimate the abundance of nanoplankton and microplankton smaller than $45 \mu \mathrm{m}$, $100 \mathrm{ml}$ of the first sub-sample were allowed to settle for $48 \mathrm{~h}$. A variable area was scanned with a Nikon inverted microscope $(\times 450)$; the scanning criterion was to count at least 300 cells of the most abundant form. To estimate the abundance of microplankton larger than $45 \mu \mathrm{m}$, material retained on the $45 \mu \mathrm{m}$ gauze was resuspended and then allowed to settle for $24 \mathrm{~h}$. The sedimented material was examined at $\times 150$ until at least 100 individuals of the most abundant organism were counted. Finally, a sub-sample from the plankton nets was examined at $\times 40$ with a similar scanning criterion to estimate mesozooplankton abundance.

Organisms were measured using non-destructive techniques with semiautomatic image analysers (Kontron IBAS-1 in 1988 and software Image Tool v 2.7 on a PC connected through a video-camera to the same inverted microscope, in 1997). Following biometrics parameters were measured: (i) major diameter $(D)$, i.e. the longest distance between the two extremes of the organisms, and (ii) minor diameter (d), i.e. the width of the mean cross section (longest perpendicular distance between two points at the edge of the organisms). The organisms were considered as approximately ellipsoidal and the individual volume $(V)$ was calculated as the 'equivalent ellipsoidal volume'
$\left(V=\left(\pi \cdot \mathrm{d}^{2} \cdot D\right) / 6\right)$. The calculated volumes for the overall size range were classified in a doubling $\left(\log _{2}\right)$ scale of individual volume (so, upper limit of size classes correspond to $1,2,4,8,16 \mu \mathrm{m}^{3}$, etc). The common output for the overall size range was then a frequency distribution of counts. Biovolume per size class can be obtained by multiplying the density by the nominal size of the class. Following Platt \& Denman $(1977,1978)$ a normalised - to the width of the size class - biomass function was used. Assuming that all the individuals within a size class are of similar size, and taking advantage of the octaval scale, the normalised biomass spectrum approaches a density spectrum. This procedure can be considered as standard for biomass spectra analysis (Rodríguez \& Mullin, 1986; Sprules \& Munawar, 1986; Gaedke, 1992; Blanco et al., 1994). Obviously, the size range of the organisms studied does not cover the whole planktonic community as very small $(<2 \mu \mathrm{m})$ cells were not considered for the analysis due to the microscopic technique used and incomplete sedimentation in Utermöhl chambers and preservation problems.

Four size spectra corresponding to 11 May, 15 June, 14 July and 10 August for station 2 in 1988 were compared with other four spectra corresponding to 12 May, 16 June, 14 July and 11 August for station 10 in 1997.

\section{Results}

The comparison between nitrate and phosphate distribution along the year at station 2 (see Fig. 3) shows that while nitrate concentration in 1988 (Fig. 3a) was always under $1 \mu \mathrm{g}$-atm N-NO$-1^{-1}$, much higher concentrations occurred in 1997 (Fig. 3b), particularly during spring and summer (just at the harvest time when larger amounts of fertilisers are used in the lagoon's watershed). The results suggest that nitrate was mainly entering into lagoon via runoff in 1988 since a positive and significant correlation was found between nitrate concentration and accumulated rainfall during the week prior to the sampling day $(r=0.45, n=21)$. Samples with concentration below the detection limit of the method were not included here. Furthermore, higher nitrate concentrations are usually found in the west coast of the lagoon, close to the mouth of the main watercourses, meanwhile lower concentrations are associated to the west coast and El Estacio channel influence area (Fig. 4). All these facts suggest that nitrate was related to the agriculture activity. 

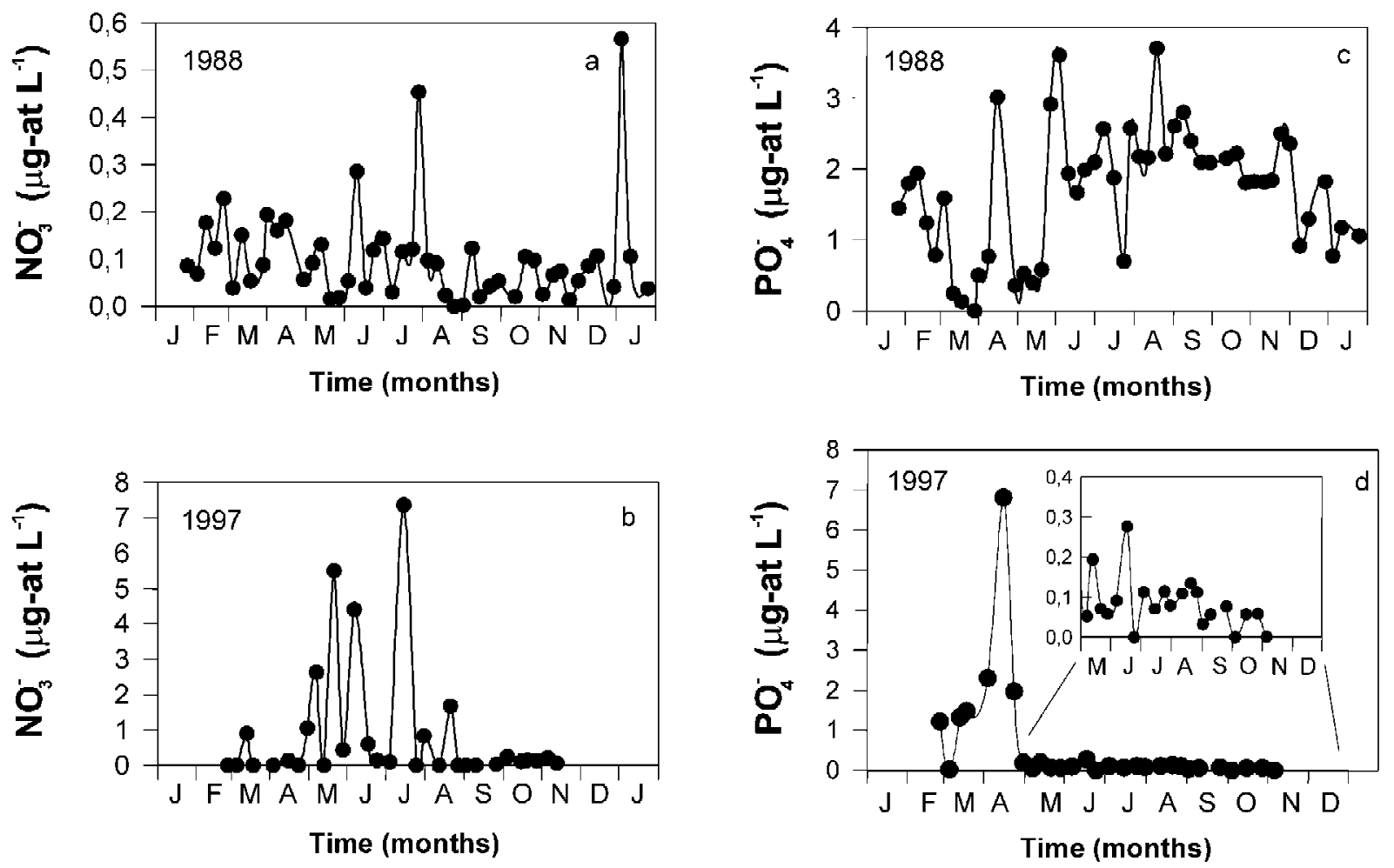

Figure 3. Temporal variation in nutrient concentration at station 2 in 1988 and 1997. (a) Nitrate in 1988, (b) nitrate in 1997, (c) phosphate in 1988 and (d) phosphate in 1997.

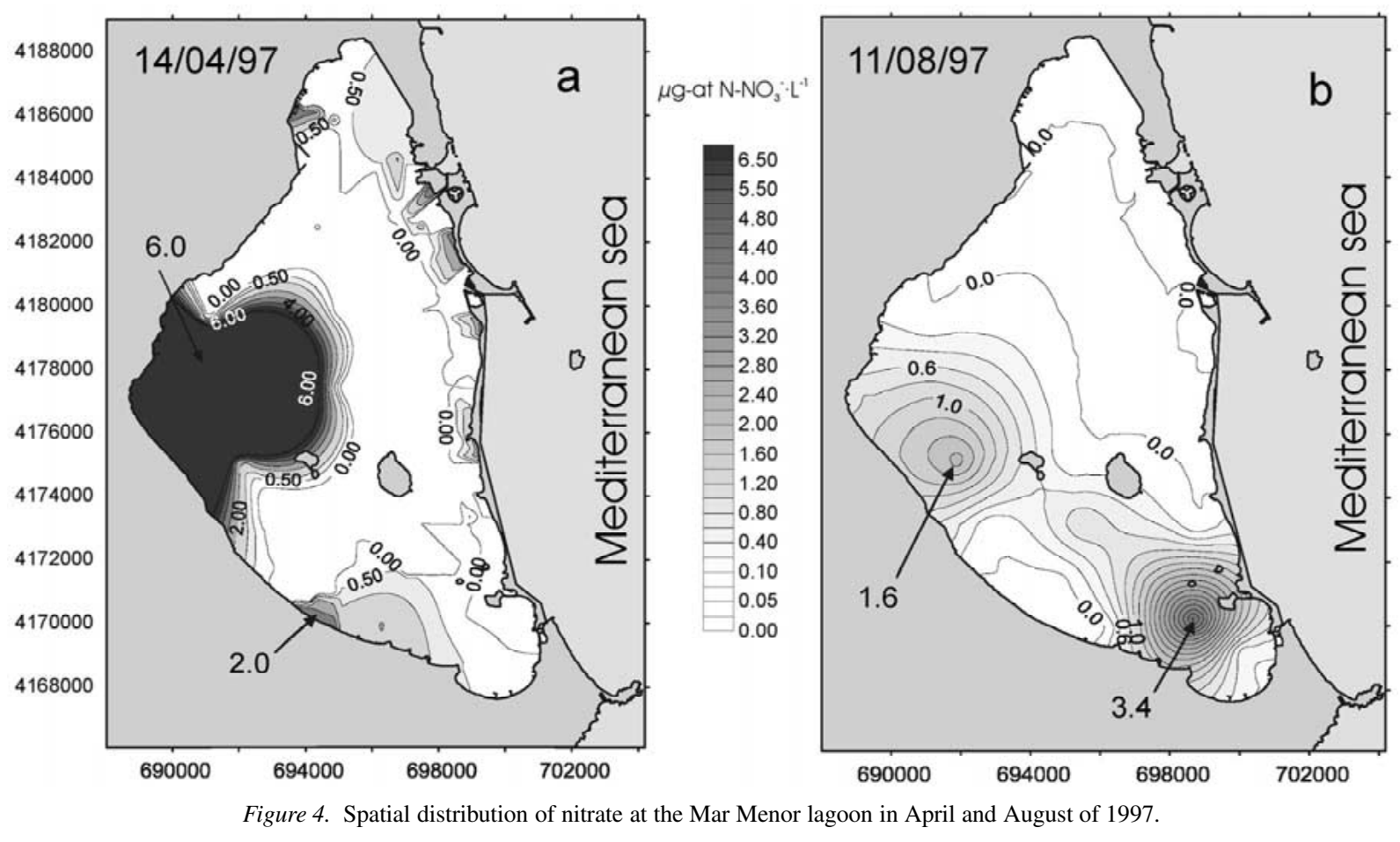




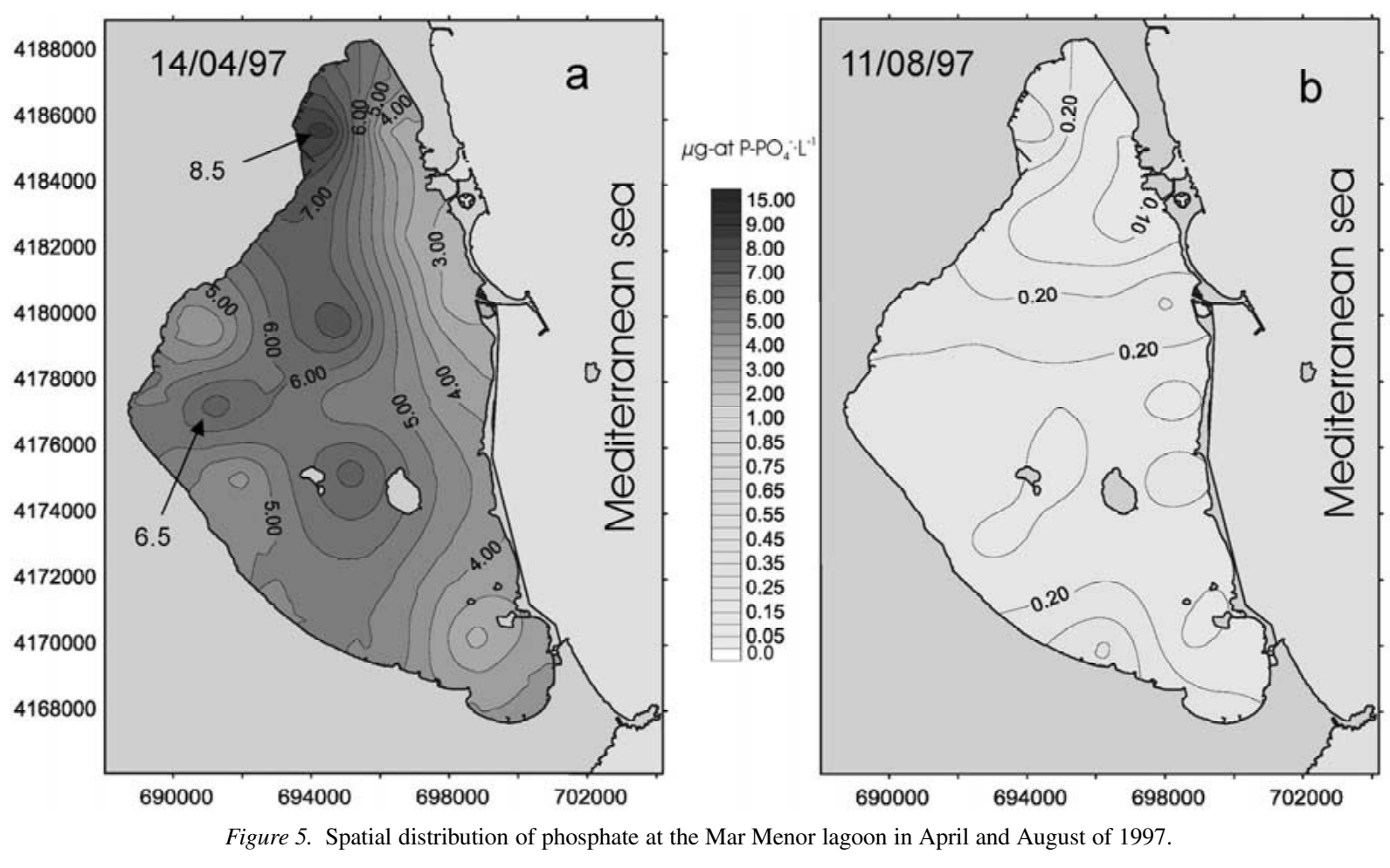

Drastic change in phosphate levels were found between 1988 (Fig. 3c) and 1997 (Fig. 3d, from May to October). This sharp decline in $\mathrm{P}$ concentrations suggests that an external cause changed the input regime for this nutrient. The trend in the data for 1988 is related to the annual temperature cycle $(r=0.53, n=44)$ which, at the same time, is related to the increase of tourist population and indirectly to sewage discharge as no urban wastewater treatment plants were installed by that time. Nevertheless, as soon as the treatment plants were installed the phosphate levels decreased significantly in 1997, except in punctual dates in April (Fig. 3d). The peak observed in April of this year probably corresponds to failures in waste management. The superficial distribution or $\mathrm{P}$ in this date shows the maximums closed to the waste pipes of the main wastewater treatment plants in La Ribera and Los Alcázares (in this case through the Albujon watercourse) (Fig. 5a).

As a consequence of changes in nutrient input regime, the water column in the lagoon has changed from being moderately oligotrophic to be relatively eutrophic providing conditions for growth of larger phytoplankton cells and subsequent changes in the trophic structure. So, phytoplankton assemblages in 1988 were mainly characterised by small flagel- lates (Crytomonads, Rhodomons and Pyramimonads), small diatoms (Cyclotella spp.) and dinoflagellates (such as Ceratium furca, which shows frequent blooms, or Prorocentrum micans) (Ros \& Miracle, 1984a, b; Gilabert, 1992) with only some short blooms of larger diatoms such as Chaetoceros sp. However, in 1997, high densities of bigger diatoms such as Coscinodiscus spp. and Asterionella spp. were also found.

The two main species of jellyfish (Rhyzostoma pulmo and Cotylorhiza tuberculata) reached annual mean densities of 0.45 and 2 individuals per $100 \mathrm{~m}^{3}$, respectively, in 1997, with local maximum densities of the second species that reached 40 individuals 100 $\mathrm{m}^{-3}$ and a total population estimated at 46.98 million of individuals (Pérez-Ruzafa et al., 1997, technical report).

A type biomass spectrum with the corresponding taxonomic groups included is shown in Figure 6. By using image analysis (a non-destructive technique), taxonomic information could be linked to individual volumetric measurements, so that each point in the size spectra can also be taxonomically characterised. The spectrum on the Figure 6 ranks the organisms from small flagellates ( $2 \mu \mathrm{m}$ diameter) to adult jellyfishes (up to $40 \mathrm{~cm}$ diameter). The fig- 


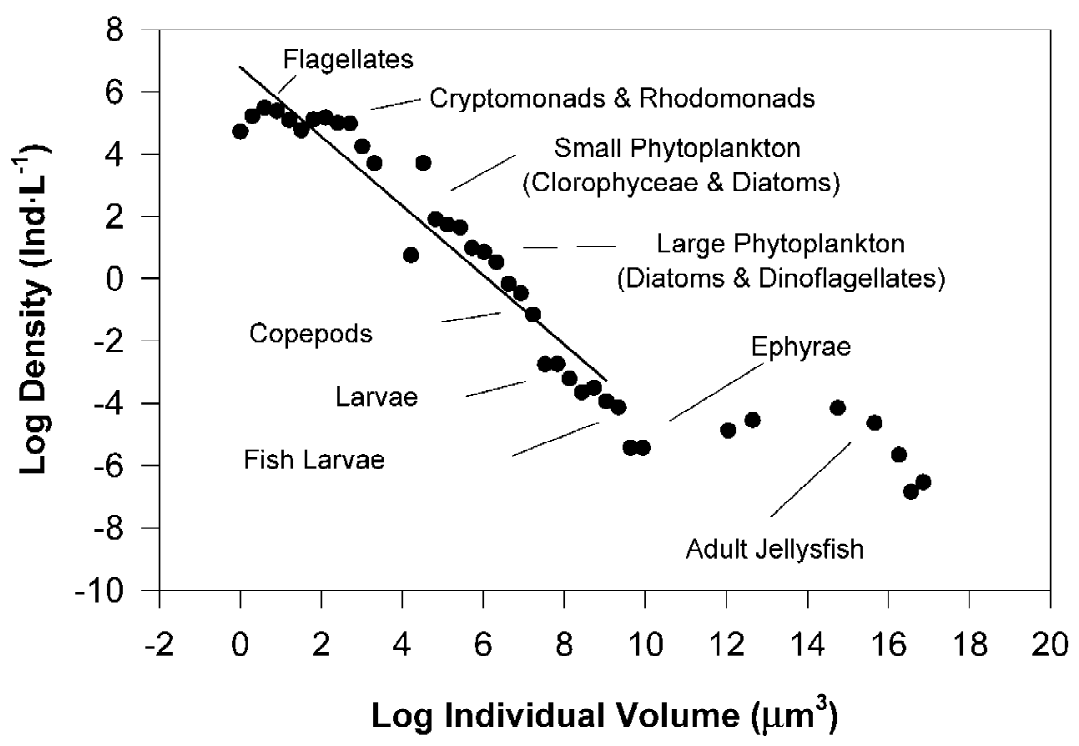

Figure 6. An example of biomass size-spectrum ranking from small flagellates ( $2 \mu \mathrm{m}$ diameter) to adult jellyfishes (up to $40 \mathrm{~cm}$ diameter). Main large taxonomic groups are indicated on plot each one spanning for several size classes. The regression line is traced excluding the region of gelatinous zooplankton to indicate that only the size range between 2 and $1000 \mu \mathrm{m}$ diameter was used in the interannual comparison.

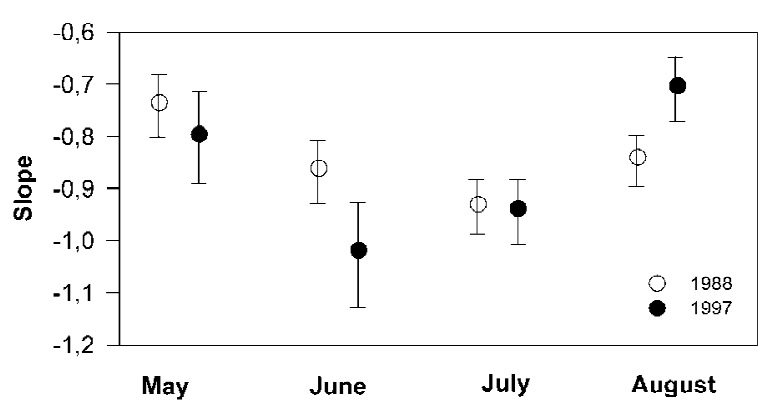

Figure 7. Comparison of the slope values of the biomass size-spectra regression lines between 1988 (open circles) and 1997 (closed circles) in 4 days from May to August.

ure shows a broad range of organisms, including small heterotrophic flagellates, other flagellates such as Cryptomonads and Rhodomonads, small and large phytoplankton, copepods, invertebrate larvae (mostly from benthic organisms) and fish larvae. Ephyrae and adult jellyfishes are included in the right side of the spectra. The regression line excludes the region of gelatinous zooplankton so that only the size range between 2 and $1000 \mu \mathrm{m}$ equivalent spherical diameter (ESD) was used for the comparisons between 1988 and 1997 (due to lack of jellyfish in 1988). Less negative slopes of regression lines of biomass spectra are found when organisms are accumulated to the right side of the spectra. On the contrary, more negative slopes can be expected when small organisms domin- ate regardless the total biovolume for the whole range of size classes considered. Although the parameters of the regression line can vary widely depending on the density of individuals in each size class, the slope of the spectra followed a similar seasonal trend in both years (see Fig. 7), suggesting that this trend is imposed by physical factors rather than strictly biological control mechanisms in this particular ecosystem. Figure 8 shows the comparison between spectra showing that total biovolume considered under the above size range was paradoxically always lower in 1997 - with higher nitrate loads, lower concentration of phosphate and very high densities of jellyfishes - than in 1988 - with lower nitrate levels, higher phosphate concentrations and where jellyfishes were not found at the sampling station.

Figure 9 shows the temporal abundance of the jellyfish species during 1997. Each data point on the plot represents the mean density value estimated from all of the 20 sampling stations. Rhyzostoma pulmo started to increase in May, while Cotylorhiza tuberculata peaked in abundance in June and July, reaching more than 12 individuals per $100 \mathrm{~m}^{3}$. The total population of jellyfishes estimated in the lagoon by mid summer in 1997 was in the order of 40 million. The gut contents of both species are expressed as percentages in Figure 10. These results show that both species of jellyfish fed predominantly on large diatoms (62.4\%) (mainly Asterionella spp. and Coscinodiscus spp.), 


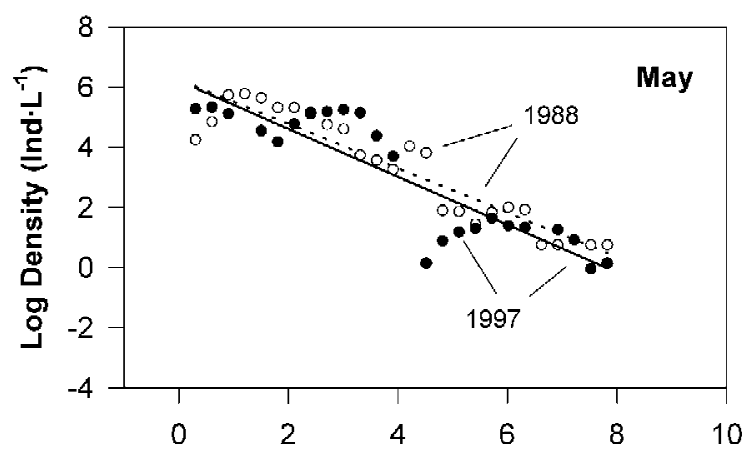

Log Individual Volume $\left(\mu \mathrm{m}^{3}\right)$

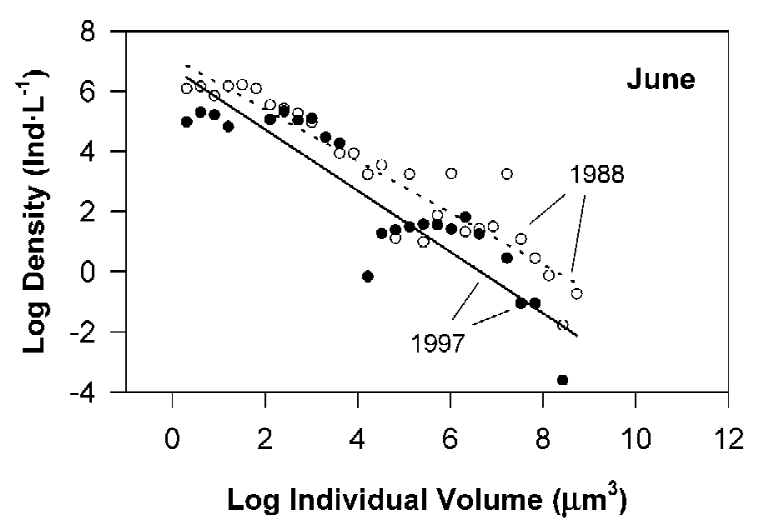



Log Individual Volume $\left(\mu \mathrm{m}^{3}\right)$

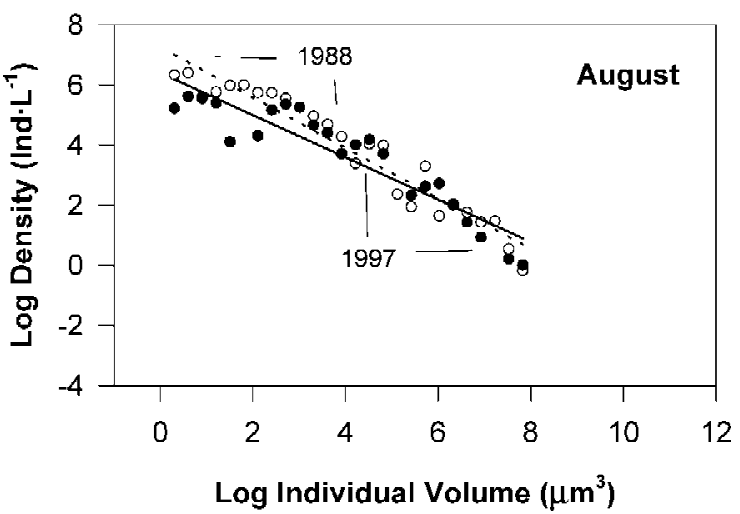

Figure 8. Comparison of biomass size-spectra between 1988 (open circles, dotted regression line) and 1997 (closed circles, continuous regression line) in 4 days from May to August.

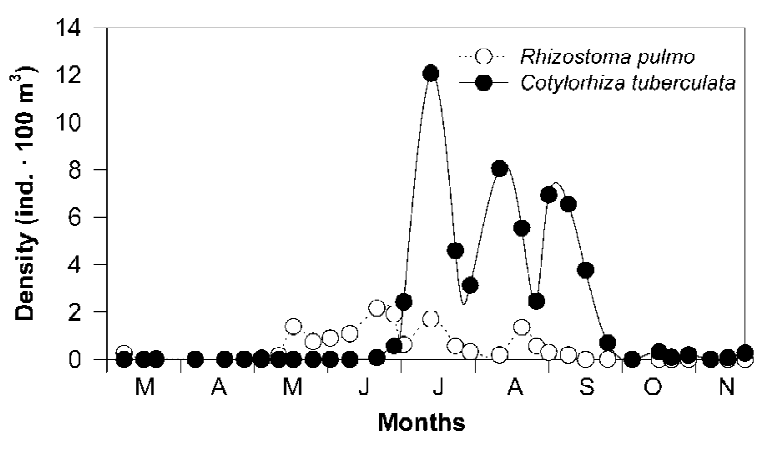

Figure 9. Temporal variation in the mean density of the jellyfishes Rhizostoma pulmo and Cotylorhiza tuberculata from March to November 1997.

followed by tintinnids. Veliger larvae accounted for 1.8 and $6 \%$ while contribution of copepods was 0.5 and $3.17 \%$, respectively.

\section{Discussion}

The comparison between nutrient concentrations in the years sampled illustrated changes in the nutrient inputs into the lagoon from 1988 to 1997. In 1988, nitrate seemed to be the main limiting factor for phytoplankton growth. Concentrations were low through the year, contrasting to the higher phosphate values. In 1997 , the N:P relationship changed drastically as a consequence of higher nitrate load and phosphate removal. Phosphate patterns in both years showed a strong relationship with seasonal changes in water temperature. The two main reasons for this relationship include: (a) the effect of seasonal increase in the human population when no urban wastewater treatment plants were in operation, and (b) the release of phosphate from sediment (Nixon et al., 1980). Peak tourist season occurs in summer months, but spans between spring and fall with a high increase in population on the lagoon coast. This meant that temperature and phosphate levels peaked together, particularly in 
Rhizostoma pulmo

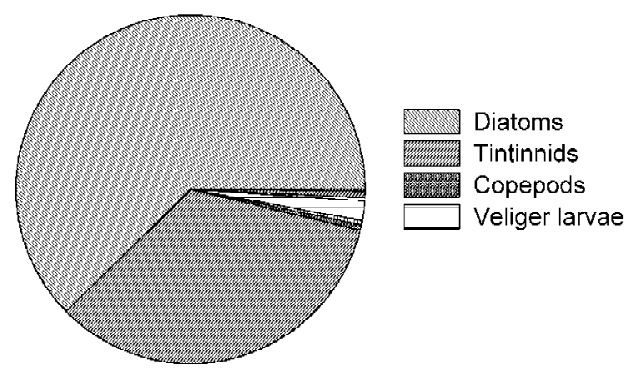

\section{Cotylorhiza tuberculata}

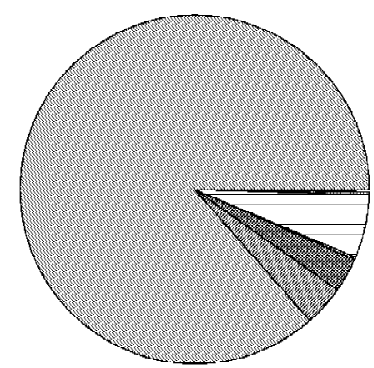

Figure 10. Relative contribution (\%) of the main dietary components in the gut contents of jellyfishes Rhizostoma pulmo and Cotylorhiza tuberculata.

1988 when there was no treated wastewater. In contrast, in 1997, when treatment plants were operational, the relationship between phosphate and temperature was probably due to substrate release rather than wastewater, although a small amount of not treated water could also entered into the lagoon. The situation for nitrate was slightly different. There were no functional watercourses draining into the lagoon in 1988 except during episodic storm and rainfall events. There was a good correlation between nitrate concentration and rainfall values. In contrast, after the rise of the phreatic levels, the major watercourse (El Albujón) was functional in 1997, discharging some freshwater into the lagoon. Spatial distribution of nitrates in the lagoon waters shows a close relationships with watercourse mouths, and mainly with the El Albujon (see Fig. 4). The extent to which this nitrate is diluted in the lagoon depends greatly on water currents, mainly driven by winds. In summary, this results suggest that nitrate was entering into the lagoon via flood runoff in 1988 and through a continuous flow from the main watercourses in 1997. They also indicate that nitrate could have been the main limiting factor for phytoplankton production in 1988, but not in 1997 .

According to ecophysiological theory, based on the size dependence nutrient uptake kinetics (Malone, 1980; Hein et al., 1995) and diffusion limitation of nutrient transport (Chisholm, 1992; Thingstad \& Rassoulzadegan, 1999), the chance for small cells to grow increases where high nutrient loads provide environmental conditions favouring the shift from small celled phytoplankton to larger cells assemblages. Small phytoplankton should outcompete large phytoplankton when nutrient are scarce, while larger phytoplankton should outcompete small phytoplankton when nutrient level increases. However, competitive success is not only determined by nutrient concentrations. Light or predation avoidance mechanisms can play also a critical role. While small cells are very efficient at absorbing light, larger cells can more easily adapt their pigment contents by packaging them in the chloroplasts improving thus their efficiency. Furthermore, large cells also develop morphological structures, and some of them migratory behaviour, for predator avoidance.

Changes in phytoplankton community structure of the Mar Menor lagoon between 1988 and 1997 are in keeping with the theory, as large sized phytoplankton, such as Asterionella or Coscinodiscus, were found in 1997 (with higher nitrate levels), but not in 1988 (with lower nitrate levels). However, it is noteworthy that in spite of higher nutrient loads, no very large interannual differences have been observed in the smaller phytoplankton fractions (Gutiérrez, pers.com.). This similarity suggests that both the detritus pathway (Newell, 1982, 1984) and the microbial loop (Azam et al., 1983), characteristic of shallow oligotrophic systems, still play an important role in transferring energy to larger organisms.

It seems evident that presence of large-celled phytoplankton in 1997 in response to elevated nitrate concentrations must have significant implications for the structure and function of the whole planktonic food web, which, should be revealed by the size structure analysis. The spectra slope has been related with the energy flow through the planktonic food web (Silvert \& Platt, 1980; Rodríguez et al., 1987; Gaedke, 1993) and with the trophic state of the ecosystem (Sprules \& Munawar, 1986). The interannual comparison of four spectra (2-1000 $\mu \mathrm{m}$ ESD) slope in the Mar Menor lagoon did not shows significant differences $(p=0.739)$ indicating that the slope's seasonal trend was maintained during both years showing no dependence on the nutrient load. Furthermore, comparison between 
spectra revealed that the total biovolume of the size range considered was always lower in 1997 than in 1988 (Fig. 8). This comparison raises the question why, at higher nutrient concentrations in 1997, planktonic biovolume in the studied size range remained lower than at lower nutrient concentration in 1988. The key to solve this paradox may to be in the topdown control mechanisms on the food web structure. Our results support the hypothesis that larger zooplankton, in this case jellyfish, can be an efficient agent top-down controlling the consequences of an eutrophication processes.

In systems where nutrient are scarce, fast-growing small cells can provide available food for certain size range of grazers, resulting in relatively high densities of copepods. Larger cells which grow at higher concentrations of nutrients, may become too large for copepods to graze upon, thereby becoming none available to larger zooplankton (mainly fish larvae and jellyfish). Jellyfish gut contents indicate clearly their preference for large diatoms, tintinnids, veliger larvae and copepods (Fig. 10). High removal rates of larger plankton are expected in the Mar Menor lagoon due to the large number of jellyfishes and their sizeselective diet. While the origin of large diatoms in the water column can be explained as a direct consequence of nitrate loads, abundance of veliger larvae is due to the high populations of benthic filter feeders molluscs in the lagoon, mainly Cardium and Ostrea. Tintinnids, the second most numerically important of gut contents, feed mainly on bacteria, heterotrophic flagellates and small phytoplankton cells (Heinbokel $\&$ Beers, 1979). This highlights the importance of the food chains based on small particles. The occurrence of tintinnids and large diatoms in the gut contents of jellyfish supports the notion that an oligotrophic food chain based on small particles and a meso-eutrophic food chain based on large phytoplankton cells co-exist in the Mar Menor lagoon. The effect of jellyfishes removing tintinnids can be, therefore, also seen as an indirect top-down control mechanism on small size fractions. By grazing copepods, jellyfish also act indirectly on small phytoplankton, reducing the top-down control exerted by copepods on small phytoplankton. This finding goes against the traditional view that eutrophication drives systems from small to large cells only. Trade-offs between direct and indirect effects can explain why some eutrophied systems support viable populations of small celled phytoplankton and large populations of large gelatinous zooplankton.
Two main reasons led us to conclude that fishes were not the main top-down controller agent in the Mar Menor lagoon: firstly, most species of fish in the lagoon either live on the seabed or are benthic or benthic feeders (A. Pérez-Ruzafa, 1989). Secondly, the pelagic fishes entering into the lagoon from the Mediterranean (mainly engraulids and atherinids) have drastically reduced their numbers in the Mar Menor lagoon after the enlargement of El Estacio.

So, the results obtained from the Mar Menor lagoon support the conclusion that large gelatinous zooplankton (jellyfishes) exert a strong top-down control on the food web by selective grazing on large diatoms, ciliates, veliger larvae and copepods. Removing large diatoms has a direct effect on nutrients load as they uptake inorganic nutrients from water column, but the simultaneous removal of grazers such as ciliates and copepods reduces the predation pressure on smaller phytoplankton allowing them to flourish. Thus, the feeding preference of jellyfish imposes a combination of direct and indirect effects on the planktonic structure at different size levels. The trade-off between competition for available resources (bottom-up) and predation (top-down) control mechanisms (Lehman, 1991; Cottingham, 1999) results in a planktonic size structure different to that thought to occur under eutrophied conditions. Further studies on trophic control mechanisms could provide very valuable insights for coastal management purposes.

\section{References}

Agawin, N. S. R., C. M. Duarte \& S. Agustí, 2000. Nutrient and temperature control of the contribution of picoplankton to phytoplankton biomass and production. Limnol. Oceanogr. 45: 591-600.

Azam, F., T. Fenchel, J. G. Field, J. S. Gray, L. A. Meyer-Reil \& F. Thingstad, 1983. The ecological role of water column microbes in the sea. Mar. Ecol. Prog. Ser. 10: 257-263.

Bartram, W. C., 1980. Experimental development of a model for the feeding of neritic copepods on plankton. J. Plankton Res. 3: 25-51.

Blanco, J. M., F. Echevarría, \& C. M. García, 1994. Dealing with size-spectra: Some conceptual and mathematical problems. In Rodríguez, J. \& W. K. W. Li (eds), The Size Structure and Metabolism of the Pelagic Ecosystem. Sci. Mar. 58: 17-29.

Cottingham, K. L., 1999. Nutrients and zooplankton as multiple stressors of phytoplankton communities: evidence from size structure. Limnol. Oceanogr. 44: 810-827.

Chisholm, S. W., 1992. Phytoplankton size. In Falkowski, P. G. \& A. D. Woodhead (eds), Primary Productivity and Biogeochemical Cycles in the Sea. Plenum Press, New York: 213-237.

DeAngelis, D. L., 1992. Dynamics of Nutrient Cycling and Food Webs. Chapman \& Hall, London. 
Fernández, J. A., F. X. Niell \& J. Lucena, 1985. A rapid and sensitive automated determination of phosphate in natural waters. Limnol. Oceanogr. 30: 227-230.

Frost, B. W., 1972. Effects of size and concentration of food particles on the feeding behavior of the marine planktonic copepod Calanus pacificus. Limnol. Oceanogr. 17: 805-815.

Gaedke, U., 1992. The size distribution of plankton biomass in a large lake and its seasonal variability. Limnol. Oceanogr. 37: 1202-1220.

Gaedke, U., 1993. Ecosystem analysis based on biomass size distributions: a case study of a plankton community in a large lake. Limnol. Oceanogr. 38. 112-127.

Geider, R. J., T. Platt \& J. A. Raven, 1986. Size dependence of growth and photosynthesis in diatoms: a synthesis. Mar. Ecol. Prog. Ser. 30: 93-115.

Gilabert, J., 1992. Análisis del ecosistema planctónico del Mar Menor. Ciclo anual, distribución de tamaños y red trófica. $\mathrm{Ph}$. D. University of Murcia.

Gilabert, J., J. Rodríguez \& F. Jiménez-Montes, 1990. The planktonic size-abundance spectrum in an oligotrophic hypersaline coastal lagoon, the Mar Menor, Murcia, Spain. In Barnes, M. \& R. N. Gibson (eds), Trophic Relationships in the Marine Environment. Aberdeen University Press, Aberdeen: 18-27.

Hein, M., M. F. Pedersen \& K. Sand-Jensen, 1995. Size-dependent nitrogen uptake in micro- and macroalgae. Mar. Ecol. Prog. Ser. 118: 247-253.

Heinbokel, J. F. \& J. R. Beers, 1979. Studies on the functional role of tintinnids in the Southern California Bight. III. Grazing impact of natural assemblages. Mar. Biol. 52: 23-32.

Kerfoot C. \& A. Sih (eds), 1987. Direct and Indirect Impacts on Aquatic Communities. University Press of New England, Hanover. 386 pp.

Lehman, J. T., 1991. Interacting growth and loss rates: the balance of top-down and bottom-up controls in plankton communities. Limnol. Oceanogr. 36: 1546-1554.

Lillo, M., 1978. Geomorfología litoral del Mar Menor. Papeles del Departamento de Geografía (Universidad de Murcia) 8: 9-49.

Malone, T. C., 1980. Algal size. In Morris, I. (ed.), The Physiological Ecology of Phytoplankton. Studies in Ecology, 7. Univ. California Press. Blackwell: 433-463.

Newell, R. C., 1982. The energetics of detritus utilisation in coastal lagoons and nearshore waters. In Laserre, P. \& H. Postma (eds), Coastal Lagoons. Oceanol. Acta. Proceeedings International Symposium on Coastal Lagoons. Special publication: 347-355.

Newell, R. C., 1984. The biological role of detritus in the marine environment. In Fasham, M. R. J. (ed.), Flows of Energy and Materials in Marine Ecosystems. Plenum Press, New York: 317344.

Niehnius, P. H., 1992. Ecology of coastal lagoons in The Netehrlands (Veerse Meer and Grevelingen). Vie Milieu 42: 59-72.

Nixon, S. W., J. R. Kelly, B. N. Furnas, C. A. Oviatt \& S. S. Hale, 1980. Phosphorous regeneration and the metabolism of coastal marine bottom communities. In Tenore, K.R. \& B.C. Coull (eds), Marine Benthic Dynamics. Univ. of South Carolina Press, Columbia (S.C.): 219-242.
Parsons, T. R., L. Maita \& C. M. Lalli, 1984. A Manual of Chemical and Biological Methods for Seawater Analysis. Pergamon Press, New York.

Pérez-Ruzafa, A., 1989. Estudio ecológico y bionómico de los poblamientos bentónicos del Mar Menor (Murcia, SE de España). $\mathrm{Ph}$. D. University of Murcia.

Pérez-Ruzafa, I. M., 1989. Fitobentos de una laguna costera. El Mar Menor. Ph. D. University of Murcia.

Peters, F., 1994. Prediction of planktonic protistan grazing rates. Limnol. Oceanogr. 39: 195-206.

Platt, T. \& K. Denman, 1977. Organization in the pelagic ecosystem. Helgol. wiss. Meeresunters 30: 575-581.

Platt, T. \& K. Denman, 1978. The structure of pelagic marine ecosystem. Rapp. P.-v. Reun. Cons. int. Explor. Mer. 173: 60-65.

Raymont, J. E. G., 1963. Plankton and Productivity in the Oceans. Vol. I. Pergamon Press, Oxford: 489 pp.

Rodríguez, J. \& M. M. Mullin, 1986. Relation between biomass and body weight of plankton in a steady state oceanic ecosystem. Limnol. Oceanogr. 31: 361-370.

Rodríguez, J., F. Jiménez, B. Bautista \& V. Rodríguez, 1987. Planktonic biomass spectra dynamics during a winter production pulse in Mediterranean coastal waters. J. Plankton Res. 9: 1183-1194.

Ros, M. \& M. R. Miracle, 1984a. Distribución temporal de las dinoflageladas del Mar Menor. Anales de Biología 2: 169-180.

Ros, M. \& M. R. Miracle, 1984b. Variación estacional del fitoplancton del Mar Menor y sus relaciones con la de un punto próximo en el Mediterráneo. Limnetica 1: 32-42.

Scheffer, M., 1998. Ecology of Shallow Lakes. Chapman \& Hall, London: $357 \mathrm{pp}$.

Silvert, W. \& T. Platt, 1980. Dynamic energy-flow model of the particle size distribution in pelagic ecosystems. In Kerfoot, W. C. (ed.), Evolution and Ecology of Zooplankton Communities. University Press of New England, Hanover (N.H.): 754-763.

Sprules, W. G. \& R. Knoechel, 1984. Lake ecosystem dynamics based on functional representation of trophic components. In Meyers, D. G. \& J. R. Strickler (eds), Trophic Interactions within Aquatic Ecosystems. Westview Press, Boulder (CO): 383-403.

Sprules, W. G. \& M. Munawar, 1986. Plankton size spectra in relation to ecosystem productivity, size, and perturbation. Can. J. Fish. aquat. Sci. 43: 1789-1794.

Terrados, J \& J. D. Ros, 1991. Production dynamics in a macrophyte-dominated ecosystem: the Mar Menor coastal lagoon (SE Spain). In Ros, J. D. \& N. Prat (eds), Homage to Ramon Margalef; or, Why there is such Pleasure in Studying Nature? Oecol. Aqua 10: 255-270.

Thingstad, T. F. \& F. Rassoulzadegan, 1999. Conceptual models for the biogeochemical role of the photic zone microbial food web, with particular reference to the Mediterranean Sea. Prog. Oceanogr. 44: 271-286.

Vaulot, D. \& G. F. Frisoni, 1986. Phytoplanktonic productivity and nutrients in five Mediterranean lagoons. Oceanol. Acta 9: 57-63. 